burnt at a white heat are leather-coloured, and have a silver-gray appearance.

The second layer (No.2) is divided into two varieties, $a$ and $b$, the former of which is black from the presence of lignite, and yields lemon-yellow bricks; this colour is due to the conversion of the cerium oxide $\mathrm{Ce}_{2} \mathrm{O}_{3}$ into the lower oxide $\mathrm{Cs}_{3} \mathrm{O}_{4}$ by the action of the carbon which is present. The $b$ variety is blackish-gray, and yields orangered to orange-yellow bricks.

The third layer contains less cerium than the other two, and the bricks made from it are of a fainter orange colour.

The amount of glucina present is very characteristic of the Hainstadt clay. Ammonium chloride, which occurs only in traces in some portions of the clay, exists in quantity in others; and in one piece which crumbled to pieces a crystal of sal-ammonia was found measuring about 2 centimetres in length and $I^{\circ} 5$ centimetres in thickness.

It will be seen from the above that the oxides of cerium which were hitherto of only theoretical interest, are now of technical importance. They have long served as colouring substances in building materials without the fact having been known, and from the large amount present in the Hainstadt clay there are prospects of their being brought into use as paints.

The variation in the colour of the bricks, already mentioned as being produced according to the degree of heat to which they are submitted in the process of burning, does not appear to be due to any action of the silicate on the ceric oxide, as the latter substance can itself be made to assume either colour by igniting it at a suitable temperature. The small amount of iron present in the clay is found to have no influence on the colour of the bricks, which however is affected by the admixture of larger quantities of iron. Dr. Strohecker mentions a number of streets in Frankfort in which houses constructed of the different sorts of cerium bricks are to be seen; the leather-coloured bricks occur in Palmstrasse, Bergerstrasse, Schleidenstrasse, Schillerplatz, Goetheplatz, \&c. ; the orange-red bricks at the police-station, the law-courts, and in the walls of the zoological garden, \&c., and the lemon-yellow bricks at a villa near the west station at Hanau, and at a house in the Verlängerte Zeil at Frankfort. The houses of the peasants near Hainstadt are built of lightly-burnt bright flesh-coloured and yellow bricks.

The somewhat remarkable fact that chemists have so long failed to recognise anything other than ferric oxide as the cause of the colours in these bricks may probably be explained by the large number of shades of colour produced by iron in its various stages of oxidation, by the presence of manganese, and by the employment of mixed clays containing the oxides of both cerium and iron.

\section{HARVARD COLLEGE MUSEUM REPORT}

$\mathrm{P}$

ROF. AGASSIZ' Report, dated October I885, has 1 just reached us, and, as usual, it presents several topics of interest. Since the first section of the Museum was inaugurated in November 1860 , the establishment has passed through many changes, and from being, at its origin, a State institution, it has gradually assumed that of an independent department of the Harvard College. While it has thus lost the immediate support of the State, it has gained the good will and interest of the students of the College, the class upon whom it must in a very great measure depend not only for its maintenance, but for its being a source of intellectual and scientific good.

During the first decade of its existence the resources of the Museum were spent in forming collections which, in some branches of science, have made it a great scientific centre. During this period of ingathering the teach- ing powers of the place were interfered with. Now this period has so far passed that the resources of the place will be chiefly expended on its teaching, its original investigations, and its publications.

The foundation of this Museum dates from the publication of the "Origin of Species." The powerful movement effected by this work on the scientific thought of the age has not failed in modifying the problems which this institution was intended by its original founder to illustrate and to solve; and rightly does the son write that, if the synoptic, systematic, faunal, or palæontological collections should cease to bear the interpretation given to them by his father (the founder), their interest and importance for the advocates of the new biology would not be one whit lessened.

It is pleasant to note that the plans of Prof. Louis Agassiz-the founder of the Museum-have been, it is known, realised, and indeed beyond his most sanguine expectations, and that his son and successor now sees the establishment of a prosperous School of Natural History, amply provided with laboratories, connected with a University, and recognising in the administration of its trusts the claims of the College and of the advanced students, as well as those of the original investigator, and giving to both the latter ample opportunity of publishing their theses or researches. It has not even forgotten the specialists, for whom it has collected vast stores-stores in every way available, as most of the specialists in Europe will gladly testify.

Very truly writes Prof. A. Agassiz in reference to original investigation, that such is always best promoted in connection with educational institutions, and we would that the fact were more recognised in these co:mtries; and in regard to museums belonging to such he suggests that they should grow so fast, and no faster, as the demand for such growth arises, otherwise they become mere unwieldy and meaningless accumulations. We may add that in countries where large museums are kept up by the State, University or College Museums on an extensive scale are a vast mista':e. The college student's needs are very limited, and the money spent on adding to and keeping up collections would be infinitely better expended as aid to original research. All experienced teachers know how small is the stock of material required for their demonstrations, and how comparatively easy nowadays it is to procure such.

Prof. Agassiz hints that it would be desirable if, in connection with the Laboratory of the United States Fish Commission, the Universities of the United States should found a sea-side laboratory, which would render unnecessary, unless for special work, the various establishments already being established along the American coast. The hint should not be lost on our own Universities and Colleges, which should be urged to assist in the establishment of the British Biological Station. A long list of donations and purchases, an account of the work done, memoirs published or assisted by the loan of collections, conclude this very interesting Report.

\section{TECHNICAL EDUCATION IN NEW SOUTH WALES}

THE progress of technical education during the last few years in this country has been watched with great interest by some of our more important colonies which are desirous of not lagging too far behind the mother country in their arrangements for giving special instruction to artisans in subjects allied to the industries in which they are engaged. The Report of the Minister of Public Instruction of New South Wales recently issued contains some interesting particulars as to the establishment of a Technical College in Sydney and the organisation of trade classes in the colony. The present 